九州大学学術情報リポジトリ

Kyushu University Institutional Repository

\title{
Temporal Change of Soil Animals of the Stockpiled Forest Topsoil in Relation to Soil Temperature and Soil Moisture
}

Park, Seok-Gon

Institute of Tropical Agriculture, Kyushu University

$\mathrm{Yi}$, Myung-Hoon

Dept. of Landscape Architecture, Graduate School, Yeungnam Univ.

Shin, Hyun-Tak

Gyeongsangnam-do Forest Environment Research Institute

Kurosawa, Kiyosi

Institute of Tropical Agriculture, Kyushu University

https://doi.org/10.5109/19531

出版情報: 九州大学大学院農学研究院紀要. 56 (1)，pp.9-13，2011-02. Faculty of Agriculture， Kyushu University

バージョン :

権利関係 : 


\title{
Temporal Change of Soil Animals of the Stockpiled Forest Topsoil in Relation to Soil Temperature and Soil Moisture
}

\author{
Seok-Gon PARK ${ }^{1}$, Myung-Hoon $\mathrm{YI}^{2}$, Hyun-Tak SHIN ${ }^{3 *}$ \\ and Kiyosi KUROSAWA ${ }^{1}$
}

\author{
Institute of Tropical Agriculture, Kyushu University, Hakozaki, 6-10-1, Fukuoka 812-8581, Japan \\ (Received October 29, 2010 and accepted November 8, 2010)
}

\begin{abstract}
The number and species of soil animals were counted, and soil temperature and soil moisture were measured monthly for the stockpiled forest topsoil during a three month stockpiling period, and their temporal change and mutual relationships were analyzed. The topsoil, collected from evergreen broad-leaved forest, was stockpiled in a container in an outdoor environment. Every factor was measured at each depth of $0.1,0.5,1$ and $1.5 \mathrm{~m}$ from the soil surface at the horizontal center of the container. As a result, the number and species of soil animals decreased with time, while the temperature and the moisture of the topsoil increased with time at all depths. The soil moisture was higher than $50 \%$ at from a $0.5 \mathrm{~m}$ to $1.5 \mathrm{~m}$ depth, however, the moisture at $0.1 \mathrm{~m}$ depth was not as high as those of the $0.5 \mathrm{~m}-1.5 \mathrm{~m}$ depth, probably due to the combined effects of infiltration, drainage and/or evaporation of rainwater in the topsoil layer, which depended on time. The temporal increase in soil temperature was perhaps brought about by the heat produced by the decomposition of the organic matter contained in the topsoil. The temporal decrease in soil animals was probably caused by the soil temperature and soil moisture, which were increased, and became unsuitable for their survival. Since preserving soil animals in the topsoil is crucial for keeping natural revegetation potential of the topsoil and to use it for recycling, rises in soil temperature and in soil moisture of the topsoil must be prevented.
\end{abstract}

\section{INTRODUCTION}

Forest topsoil is used as a soil seed bank for keeping natural revegetation potential. Soil seed banks prevent the disruption of gene pools caused by the intrusion of vegetation from other areas and enable the recycling of the natural resources (Hosogi et al., 2004). By the technique of using soil seed banks, pioneer species can be germinated from the topsoil and accordingly vegetation can be restored quickly. Furthermore, the technique can also preserve soil animals and microorganisms, such as worms and arbuscular mycorrhizal fungi. The technique has drawn much attention recently because it prevents the destruction of local ecosystems by land development (Morimoto and Kameyama, 2001). The dam construction project of Minogawa-Dam in Osaka Prefecture, conducted in 1980-1983, is a representative case where the technique was applied to the dam lakefront slope for revegetation. By the application, the forest has developed and small animals and landscape have been preserved on the slope (Morimoto and Kameyama, 2001). There are some diverging methods of the technique: i.e. scattering of topsoil on the devastated area (Sato et al., 1999; Nakamura et al., 2002), mixing glue with topsoil and scattering and/or pasting it on the slope (Nakamura et al., 2004) and piling up of sandbagged topsoil on slope surfaces (Yabu et al., 2000). However recently, a new method to recycle the topsoil on land has developed which uses heavy equipment without disturbing the top-

\footnotetext{
Institute of Tropical Agriculture, Kyushu University, Fukuoka 812-8581, Japan

Dept. of Landscape Architecture, Graduate School, Yeungnam Univ., Gyeongsan 712-749, Korea

Gyeongsangnam-do Forest Environment Research Institute, Jinju 660-871, Korea

* Corresponding author (E-mail: twinshin@hanmail.net)
}

soil (Song et al., 2001).

The topsoil collected from the construction site should be stockpiled for a certain period until it will be put back as a plant base in the land development or road development project. During that period, the natural revegetation potential of topsoil will decrease in parallel with the decrease in soil animals, microorganisms and buried seeds (Hosogi and Matsue, 2010). At present, some amendment process must be included in topsoil stockpiling, and therefore study on maintaining the natural revegetation potential of topsoil is required.

On the other hand, Song and Setsu (2004) and Yamabe and Ogura (2004) showed that the improvement of the natural environment can be evaluated using soil animals for a transplanted topsoil in a damaged forest. The soil animals are found widely from primeval forests to big cities depending on its species, and are observed all year round. The soil animals have not only a characteristic to change species composition with soil environment but also another characteristic of sedentariness for each single species, which can be utilized as an indicator of natural environment (Aoki, 1995).

This study aimed to find out how the soil animals, soil temperature and soil moisture of the topsoil change with time what causes it whether or not the temporal change of the soil animals can be explained by soil temperature and soil moisture and if there is a better method to stockpile topsoil using these results, respectively.

\section{MATERIALS AND METHODS}

\section{Sampling and stockpiling of topsoil}

The topsoil for the experiment was collected from several spots of $A_{0}$ and $A_{1}$ layers of an evergreen broadleaved forest in the Fukuoka Forest of Kyushu University. After removing the leaves, the topsoil was mixed so that 
the topsoil might have a homogeneous physical structure. A wooden container $(0.9 \mathrm{~m}$ length $\times 0.90 \mathrm{~m}$ width $\times 1.5 \mathrm{~m}$ height) was installed in an outdoor location, and the topsoil was piled up in the container. In order to block heat conduction from the exterior of the container, the container's sides were covered with $40 \mathrm{~mm}$ thick polystyrene. The rainfall could infiltrate into the ground from the surface into the ground, and the rainfall water could be drained from the bottom of the container naturally. The collection of the topsoil and stockpiling of it were done in May, 2004.

For comparing the topsoil with other soils, a decomposed granite (DG) soil was piled up in the same manner as the topsoil. DG soil contains only a little amount of organic matter in general (Masuda, 1992). The DG soil was sampled from the Fukuoka Forest of Kyushu University.

\section{Measurement of soil temperature and soil moisture}

A temperature sensor (Thermo Recorder TR-51) and a soil moisture sensor (EC-20 ECHO) were set at the positions of $0.1,0.5,1$ and $1.5 \mathrm{~m}$ depths in the topsoil, and the soil temperature and dielectric constants of the topsoil were measured by these sensors every 10-minutes. The volume water content (\%) of the topsoil was measured by an oven-drying method for the sampled topsoil at each depth at 15-day intervals. The regression formula between the volume water content (\%) and dielectric constant was generated from the measurements from the 15-day intervals. After, the volume water content (\%) at each 10-minute interval was calculated from the dielectric constant measured at the corresponding time. The measurements of the soil temperature and soil moisture were done for 3 months from June $12^{\text {th }}$ through September $15^{\text {th }}$ in 2004.

For the DG soil, the soil temperature was also measured in the same manner as the topsoil. The measurements were done only in September, 2004.

\section{Measurement of air temperature and rainfall}

Air temperature was measured in a shady place near the container where the topsoil was stockpiled. The measurement was done by a temperature sensor (Thermo Recorder TR51) every 10-minutes at a height of $1.5 \mathrm{~m}$ above the ground. The term of the measurement was the same as that of the soil temperature. The daily mean air temperature was calculated using each 10-minute air temperature. The rainfall data was obtained from the university forest office. Rainfall was observed near the location of the container.

\section{Investigation of soil animals and evaluation of soil environment}

The individual number of soil animals and species were counted monthly during the experimental period. In the counting, $0.002 \mathrm{~m}^{3}$ of topsoil was sampled from each depth of the container. The large and visible soil animals were collected using an aspirator or tweezers. The medium soil animals, which were invisible, were collected using a Tullgren device (Aoki, 1995). These soil animals were used to evaluate the living environment for soil animals by Aoki's method (Aoki, 1995). In this method, the soil animals were classified into 3 groups using 32 index species as follows; group A: 10 species of Opilones, Scolopendromorpha, Gastropoda, Diplopoda, Geopilomorpha, Pselaphidae, Symphyla, Amphipoda, Thysanura and Lygiidae. These species are observed in a relatively good soil environment. The species are easy to become extinct due to their low resistance to the environment. Group B: 14 species of Pseudoscorpiones, Oligochaeta, Dipulura, Thysanoptera, Lithobiomorpha, Isoptera, Dermaptera, Lepidoptera (larvae), Porcellionidae, Coleoptera, Curculiomidae, Coleoptera (larvae), Hemiptera and Harpalidae. These species have a medium resistance to the environment. Group C: 8 species of Collembola, Acari, Araneae, Armadillidiidae, Diptera (larvae), Enchytraeidae, Formididae and Staphylinidae. These species have a high resistance to environmental stress and can survive in a deteriorated environment. If any species of group A were observed, 5 points were given, and if any species of groups $\mathrm{B}$ or $\mathrm{C}$ were observed, 3 or 1 points were given, respectively. Points were not accumulated if more than one individual was observed for a species. If all species from groups A, $\mathrm{B}$ and $\mathrm{C}$ were observed, the total points became 100. If the point total was close to 100 , the degree of natural environment was evaluated as very good, while if the total point was close to 0 , the degree was evaluated as very poor (Aoki, 1995).

\section{RESULTS AND DISCUSSION}

\section{Temporal changes in soil temperature and soil moisture of the topsoil}

At a $0.1 \mathrm{~m}$ depth of the topsoil, the daily mean soil temperature changed in parallel with the daily mean air temperature during the experimental period (Fig. 1). This is thought to have been caused by the heat gain from solar radiation. The soil temperature at $0.5 \mathrm{~m}$ and $1 \mathrm{~m}$ depths were higher by $7-8{ }^{\circ} \mathrm{C}$, and that at $0.1 \mathrm{~m}$ and $1.5 \mathrm{~m}$ were higher by $3-4^{\circ} \mathrm{C}$ than the air temperature, respectively (Fig. 1). Generally, soil is comprised of three phases and has low heat conductivity, thus the soil temperature decreases as the position becomes deeper during the spring and summer seasons (Hillel, 1998). Different from general soil, the topsoil showed a higher temperature at $0.5 \mathrm{~m}$ and $1 \mathrm{~m}$ depth at the than other depths.

The soil temperature of the DG soil was highest at a $0.1 \mathrm{~m}$ depth and it became lower as the depth became deeper (Fig. 2). The temperature of the topsoil was higher than that of the DG soil at $0.5 \mathrm{~m}, 1 \mathrm{~m}$ and $1.5 \mathrm{~m}$ depths. The reason is considered to be as follows; Rainfall infiltrated into the topsoil. The organic matter in the topsoil was decomposed and then the soil temperature was raised by the heat of the decomposition as heat is produced by fermentation when organic matter is decomposed (Kanazawa, 2002). Thus, the soil temperature was higher in the topsoil than the DG soil that contains little amounts of organic matter. 


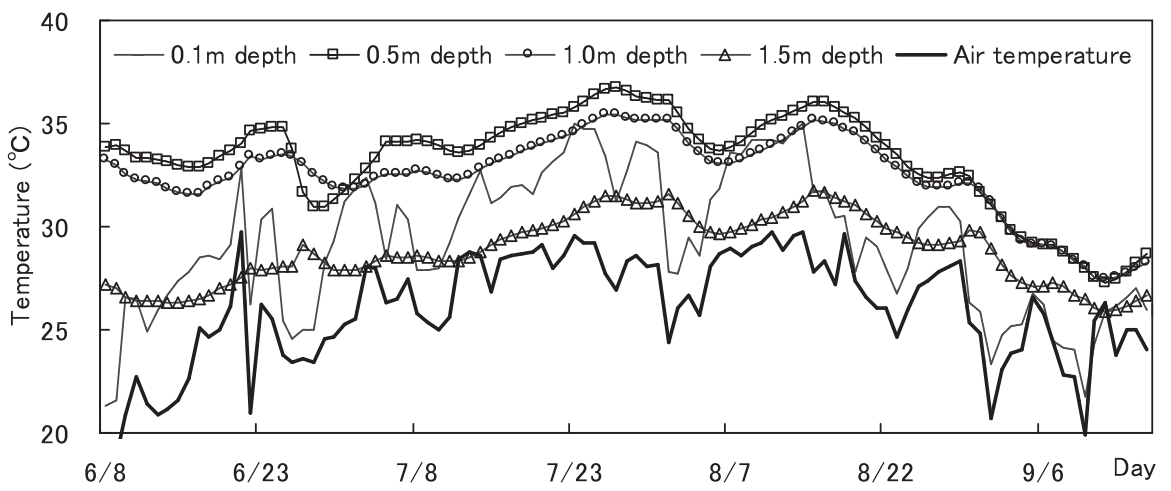

Fig. 1. Temporal change in soil temperature of the stockpiled topsoil at each depth.

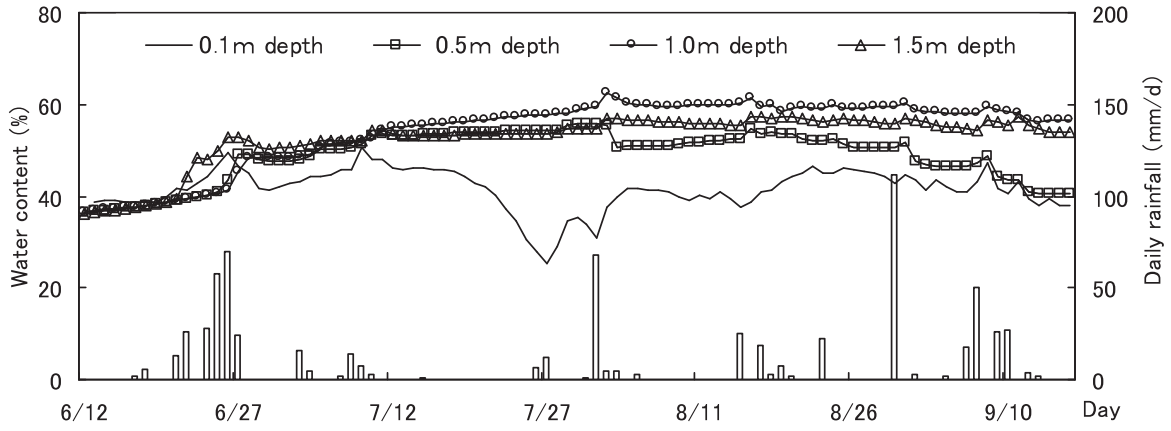

Fig. 2. Temporal change in volume water content of the stockpiled topsoil at each depth.

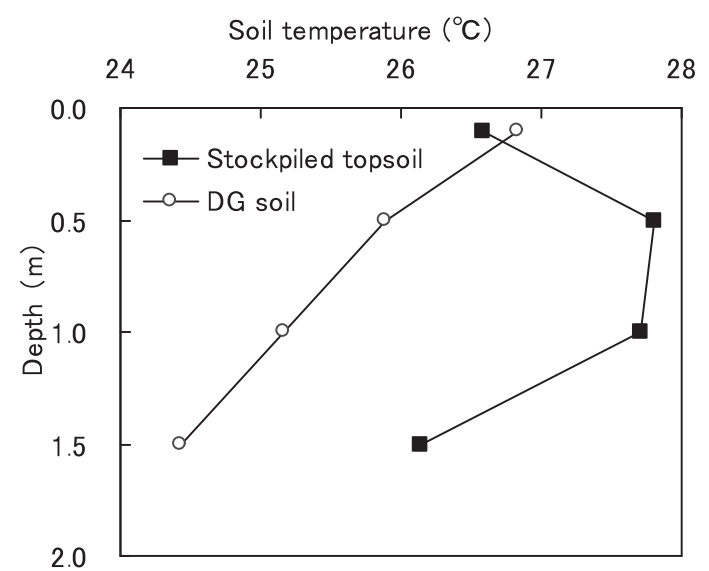

Fig. 3. Comparison of daily mean temperature between the stockpiled topsoil and decomposed granite (DG) soil.

The volume water content of the topsoil increased at all depths after June $24^{\text {th }}$ with time, which is thought to be due to rainfall infiltration into the ground. The volume water contents at a $0.1 \mathrm{~m}$ depth were increased by $25 \%$ and $50 \%$ during the light and heavy rainfall periods (last halves of July and June, respectively), respectively, showing a significant response to rainfall. In contrast, the volume water content showed a small fluctuation at $1 \mathrm{~m}$ and $1.5 \mathrm{~m}$ depths during the light and heavy rainfall periods, though the content exceeded 50\%, suggesting that little rainfall infiltrated into these depths. Moreover, the content at $1 \mathrm{~m}$ and $1.5 \mathrm{~m}$ depths was the highest, followed by that at a $0.5 \mathrm{~m}$ depth and then that at a $0.1 \mathrm{~m}$ depth. This characteristic could be the combined effect of the infiltration and evaporation of rainwater. The content at $0.1 \mathrm{~m}$ and $0.5 \mathrm{~m}$ depths was low, indicating that evaporation occurred intensively at these depths.

When the soil porosity was at 50-60\%, some pore spaces were filled with water, and in the remaining spaces, gas exchange with the atmosphere occurred. As the air filled porosity increased, the gas exchange increased, too (Foth, 1984). As shown in the present experiment, when the volume water content was larger than 50\%, soil moisture occupied most of the soil pores, hindering the gas exchange. If the gas exchange is hindered, the soil enters a reduced condition, and activity of anaerobic bacteria is enhanced. As a result, iron, manganese and organic matter in the soil are changed to the reduced compounds. These compounds are toxic and will adversely affect the plant and soil animals (Hillel, 1998).

\section{Temporal change of soil animals and evaluation of the soil environment}

Twenty-two species of soil animals were found in the topsoil, and the total number of individuals was about 410. Just after the stockpiling, all the soil animals from group A and a portion of the soil animals from group B disappeared, which were 12 species and 190 
individuals in total. In the first month after the stockpiling, the total number of species became the minimum. After that, the total number of species increased slightly with time. In the second month after the stockpiling, the total number of individuals decreased, however, it increased again in the third month after the stockpiling (Fig. 4). Natural forest has a higher number of species and individuals of soil animals than those of artificial forests of Japanese cedar (Cryptomeria Japonica) forest (Watanabe, 1973), and the number of species and individuals were higher in the over-matured forest than in the middle-aged forest (Touyama and Nakagoshi, 1994).

The results of the evaluation of the degree of natural environment using soil animals by Aoki's method was as
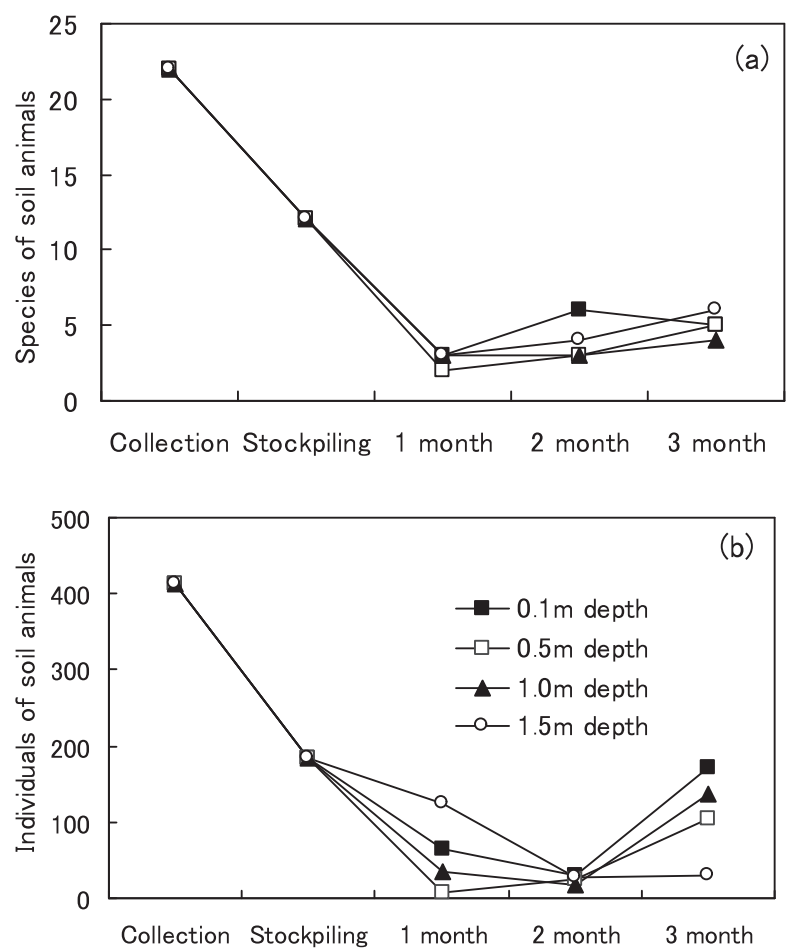

Fig. 4. Change in the number of species (a) and the number of individuals (b) of the soil animals of the topsoil. follows: 60 points during topsoil sampling, 20 points just after stockpiling, and 2-5, 3-10, and 6-10 points for the first month, second month, and third month after stockpiling, respectively, showing a temporal decrease in soil animals in groups B and C (Table 1). However, almost no species were found in group A after the stockpiling except at a $0.1 \mathrm{~m}$ depth in the third month (Table 1 ).

In the over-matured forest of Japanese cedar, Japanese red pine (Pinus densiflora) and Konara-cork oak (Quercus serrata-Q. variabilis), the degree of natural environment showed a high of 65-70 points, while in young Japanese cypress (Chamaecyparis obtusa) forest, the degree showed a low of 18 points (Touyama and Nakagoshi, 1994). Various soil animals can be observed in forests where there are various foods and the habitat environment is diversified (Touyama and Nakagoshi, 1994) and the quantity thought to be high.

The number and species of soil animals from group A rapidly declined with time, which was the effect of the degraded and simplified habitat environment for soil animals caused by the excessive soil moisture and increased soil temperature of the topsoil. Soil animals from groups $\mathrm{B}$ and $\mathrm{C}$, which have a medium resistance or high resistance to the environment, seemed to have increased with time.

\section{A better method for stockpiling topsoil}

With the increase in soil moisture by rainwater infiltration into the ground, organic matter was decomposed, and soil temperature of the topsoil became higher than before. Many species of soil animals disappeared from the topsoil in the process of transportation, soil mixing, and stockpiling. Excluding the species insensitive to the change in the temperature and moisture of the topsoil, most species were considered to become extinct or moved to another location.

A seed germination experiment conducted in the Banksia woodlands of Australia showed that $78 \%$ and $61 \%$ of species, and $54 \%$ and $34 \%$ of the number of individuals decreased after 1 and 3 years, respectively (Rokich et al., 2000). Hosogi and Matsue (2010) conducted another seed germination experiment for topsoil

Table 1. Evaluation of the habitat environment for soil animals in the topsoi

\begin{tabular}{|c|c|c|c|c|c|c|c|c|c|c|c|c|c|c|c|}
\hline & & \multicolumn{14}{|c|}{ Time } \\
\hline \multirow{2}{*}{\multicolumn{2}{|c|}{ Soil animals }} & \multirow{2}{*}{$\begin{array}{l}\text { Collec } \\
\text {-tion }\end{array}$} & \multirow{2}{*}{$\begin{array}{c}\text { Stock } \\
\text {-piling }\end{array}$} & \multicolumn{4}{|c|}{1 month } & \multicolumn{4}{|c|}{2 month } & \multicolumn{4}{|c|}{3 month } \\
\hline & & & & $0.1 \mathrm{~m}$ & $0.5 \mathrm{~m}$ & $1 \mathrm{~m}$ & $1.5 \mathrm{~m}$ & $0.1 \mathrm{~m}$ & $0.5 \mathrm{~m}$ & $1 \mathrm{~m}$ & $1.5 \mathrm{~m}$ & $0.1 \mathrm{~m}$ & $0.5 \mathrm{~m}$ & $1 \mathrm{~m}$ & $1.5 \mathrm{~m}$ \\
\hline \multirow{4}{*}{$\begin{array}{l}\text { Number } \\
\text { of species }\end{array}$} & $\begin{array}{l}\text { Group A } \\
\text { (5point) }\end{array}$ & 5 & - & - & - & - & - & - & - & - & - & 1 & - & - & - \\
\hline & $\begin{array}{l}\text { Group B } \\
\text { (3point) }\end{array}$ & 9 & 4 & 1 & - & - & - & 2 & 1 & - & 1 & - & 2 & 1 & 2 \\
\hline & $\begin{array}{l}\text { Group C } \\
\text { (1point) }\end{array}$ & 8 & 8 & 2 & 2 & 3 & 3 & 4 & 2 & 3 & 3 & 4 & 3 & 3 & 4 \\
\hline & Total & 22 & 12 & 3 & 2 & 3 & 3 & 6 & 3 & 3 & 4 & 5 & 3 & 4 & 6 \\
\hline \multicolumn{2}{|c|}{$\begin{array}{c}\text { Degree of natural } \\
\text { environment }\end{array}$} & 60 & 20 & 5 & 2 & 3 & 3 & 10 & 5 & 3 & 6 & 9 & 9 & 6 & 10 \\
\hline
\end{tabular}


collected from a deciduous forest, covering the topsoil by polyethylene for 1 year. The result showed that the germination rate of soil seed to have a high of $93.5 \%$ and $88.2 \%$ for the number of species and individuals, respectively, at one year after the stockpiling.

The revegetation technique applied in the Minogawa Dam project (Morimoto and Kameyama, 2001) was a successful case by piling up sandbagged topsoil with ventilation, drainage and subsequent scattering of the topsoil on the slope. From the present study, it was found that excessive soil moisture and/or an increase in soil temperature of the topsoil decreases the number and species of soil animals and buried seeds. Therefore, proper measures are necessary to be taken to keep the natural restoration potential.

As the measures, the stockpiling period until it will be placed back must be shortened. The site for stockpiling should be decided not to disrupt the ecological formation, and not to harm the nature of the topsoil. For stockpiling a large quantity of topsoil, a truncated coneor pyramid- or a square-shaped mound should be constructed to minimize the rainwater infiltration. If the soil moisture and soil temperature are increased, soil animals and soil seeds will be negatively affected by the decomposition of soil organic matter, and thus the natural restoration potential will be degraded.

Therefore, the slope of the mound of stockpiling should be steep in order to run off rainwater quickly from the surface. Installation of a draining ditch surrounding the mound may have an advantage to drain rainwater quickly from the mound. Installation of culverts at the bottom inside the mound may also have an advantage to drain the infiltrated rainwater. Moreover, the surface of the mound should be hardened or covered with shading to protect the mound surface from soil erosion.

\section{CONCLUSIONS}

The following conclusions were drawn from the present study. The number and species of soil animals decreases with time, when the temperature and the moisture of the topsoil increase with time at all depths. Increases in soil temperature are perhaps caused by the heat produced by decomposition of the organic matter contained in topsoil. Increass in soil moisture are caused by infiltration of rainwater. Decreases in the number and species of soil animals are caused by degradation of the soil environment. Decreases in the number of species and individuals are explained by the increases in soil temperature and soil moisture. Increases in soil moisture and in soil temperature must be prevented in the stockpiling of topsoil. For quick draining and preventing rainfall infiltration, a truncated cone - or pyramid- or a squareshaped mounding of topsoil are effective, and installation of ditches surrounding the mound and culverts in the bottom of the mound could be effective.

\section{ACKNOWLEDGEMENTS}

We would like to thank Dr. T. Setsu of Kyushu
University Forest and Dr. J. T. Song of Oak Valley Inc. for the support in planning the experiment and in conducting the investigation of soil animals.

\section{REFERENCES}

Aoki, J. 1995 Environmental diagnosis by the soil animal: An influence on natural environments prediction - result and an investigation manual. Chiba environment adjustment section, pp. 197-222 (in Japanese)

Foth, H. D. 1984 Fundamentals of soil science 7th. Ed. Wiley. pp. 435

Hillel, D. J. 1998 Environmental soil physics. Academic Press. pp. 771

Hosogi, D. and M. Matsue 2010 Competence of forest topsoil as revegetation material after stockpiling for one year. J. Jpn. Soc. Reveget. Tech., 35: 462-472 (in Japanese with English summary)

Hosogi, D., S. Yonemura and A. Kameyama 2004 Potential of forest soil seed bank as revegetation material in Kanto district and its examination method. J. Jpn. Soc. Reveget. Tech., 29: 412-422 (in Japanese with English summary)

Kanazawa, S. 2002 The production of high quality farmyard manure and new biological evaluation of compost maturity. Soil microorganisms, 56: 45-54 (in Japanese)

Masuda, T. 1992 Studies on the characteristics of Masa soil as a medium for tree growth and methods for its improvement. $J$. Jap. Inst. Landscape Arch., 56: 138-145 (in Japanese)

Morimoto, Y. and A. Kameyama 2001 Ecological mitigation in theory and practice. Soft Science, INC. pp. 310-324 (in Japanese)

Nakamura, A., T. Kinugasa, T. Jimmon, S. Taniguchi, H. Sato and Y. Morimoto 2002 Evaluation of revegetation using forest top soil by seed density, species and diversity-area curves. $J$. Jpn. Soc. Reveget. Tech., 28: 79-84 (in Japanese with English summary)

Nakamura, K., T. Ishizaka and S. Taniguchi 2004 A case study on the revegetation method using topsoil seed bank. J. Jpn. Soc. Reveget. Tech., 30: 253-256 (in Japanese with English summary)

Rokich, D. P., K. W. Dixon, K. Sivasithamparam and K. A. Meney 2000 Topsoil handling and storage effects on woodland restoration in Western Australia. Restor. Ecol., 38: 196-208

Sato, H., H. Tsutsumi, Y. Morimoto and Y. Takigawa 1999 A preliminary study of revegetation of disturbed area from forest seed banks. J. Jap. Inst. Landscape Arch., 62: 521-524 (in Japanese with English summary)

Song, J. T. and T. Setsu 2004 The validity of the floor vegetation and the soil fauna as an index of ecosystem recovery of reclamation forest. J. Jpn. Soc. Reveget. Tech., 30: 21-26 (in Japanese with English summary)

Song, J. T., T. Setsu and J. N. Bae 2001 Studies on the transplant of the trees using an exclusive machine. J. Jap. Inst. Landscape Arch., 64: 517-520 (in Japanese with English summary)

Touyama, Y. and N. Nakagoshi 1994 A comparison of soil arthropod fauna in coniferous plantations and secondary forests. Jap. J. Ecol., 44: 21-31 (in Japanese with English summary)

Watanabe, H. 1973 Effect of stand change on soil macro animals. J. Jap. For. Soc., 55: 291-295 (in Japanese with English summary)

Yabu, S., H. Yamada, A. Nakashima and S. Nakao 2000 The estimation for the slope plantings by using the forest surface soils packed in sandbags. J. Jap. Inst. Landscape Arch., 63: 447450 (in Japanese with English summary)

Yamabe, S. and I. Ogura 2004 The soil fauna consisted of transplanting topsoil and effect of restoration of natural environment. J. Jpn. Soc. Reveget. Tech., 30: 247-248 (in Japanese) 